\title{
Patterns of rare earth and other trace elements in Paleogene and Miocene clayey sediments from the Mondego platform (Central Portugal)
}

\author{
J.V. Lisboa ${ }^{a}, *$, D.P.S. de Oliveira ${ }^{a}$, F. Rocha ${ }^{b}$, A. Oliveira ${ }^{a}$, J. Carvalho ${ }^{a}$ \\ a Laboratório Nacional de Energia e Geologia, I.P. (LNEG), Portugal \\ b Geobiotec, Geosciences Dep., Univ. Aveiro, 3810-193 Aveiro, Portugal
}

\section{A R T I C L E I N F O}

\section{Article history:}

Received 22 July 2014

Received in revised form 9 June 2015

Accepted 6 July 2015

Editorial handling - M. Dietzel

\section{Keywords:}

Clay

Rare earth elements

Trace elements

Monteira Member

Arroça Member

Provenance

\begin{abstract}
A B S T R A C T
In the present study the origin of clay deposits occurring in an inland platform, in central Portugal, was investigated by their mineralogical and chemical composition. The clay deposits, exploited for ceramic industry are composed of silt-clay facies, the Monteira Member and the Arroça Member, which are assigned to the Coja Formation (Paleogene) and the Campelo Formation (Miocene), respectively. These clayey facies show almost compositional homogeneity, especially concerning texture. The mineralogical composition of the Monteira Member displays slightly higher content in smectite and interstratified clay minerals, which is supported by the chemical composition of samples analyzed. Both members present similar REE patterns, displaying an intense weathering record and little variation in the source area composition. Minor element geochemistry suggests low content in heavy minerals and transition metals. REE patterns and ratios of geochemical parameters support the dominant metasedimentary provenance, with a granite source contribution and also mature recycled sediments of continental origin. The study results' suggest that the clays of these two members have the same source in terms of lithology and recycled sediments from the Hesperian massif. During the deposition of the Arroça Member, a major remobilization of the Monteira Member is suggested, explaining the geochemical similarity of both facies.
\end{abstract}

(c) 2015 Elsevier GmbH. All rights reserved.

\section{Introduction}

The sediments' chemical composition result from a combination of factors such as: the composition of the source area, intensity of alteration, calibration and sediment diagenesis, which will determine its final characteristics (Piper, 1974; McLennan, 1989). This paper focuses on the geochemical characterization of silt-clay facies that constitute important clay resources for construction ceramics and integrate deposits occurring in inland basins, west of Coimbra, in the designated Mondego platform. These facies mostly belong to two formations, assigned respectively to the Paleogene and Neogene: Coja and Campelo formations (Cunha, 1992), which have been studied before, from a stratigraphic and sedimentological approach (Carvalho, 1960; Soares et al., 1983; Cunha, 1992, 1999). More recently these formations' silt-clay facies were assessed regarding the relationship between the composition and

\footnotetext{
* Corresponding author at: LNEG, Estrada da Portela, Bairro do Zambujal, Alfragide, Apdo 7586, 2610-999 Amadora, Portugal.

E-mail address: vitor.lisboa@lneg.pt (J.V. Lisboa).
}

most relevant ceramic properties (Lisboa, 2009; Lisboa et al., 2013) as both facies provide the main supply of clays for ceramics in the Mondego planation.

The composition and particularly the presence of lithic clasts suggest a metasedimentary and granitic provenance; the latter especially concerning the Coja formation (Reis et al., 1991), but so far geochemical techniques have not been applied to the provenance assessment or the tectonic setting of these sediments. Other studies within the study area broaching mineralogy and geochemistry of Cretaceous sediments were carried out by Prudêncio et al. (1988, 1989).

This study complements the preliminary geochemical study performed on the major elements (Lisboa, 2009) of the silt-clay facies, towards a better knowledge on the provenance, tectonic setting and weathering in the source area, using trace elements and REE, on which studies regarding these sediments are not known. As these facies present similar compositional characteristics, particularly from a textural point of view, hindering its distinction, the geochemical characteristics of both facies are examined in an attempt to reveal relationships or, on the opposite, distinctive geochemical signatures if any, among the sediments. Given that 